\title{
LANGUAGE LEARNING STRATEGIES: A CASE STUDY WITH ENGLISH JUNIORS AT DALAT UNIVERSITY
}

\author{
Nguyen Do Thien Vu*, Le Van Tuan Khoa, Le Thi Phuong Hoa
}

Dalat University

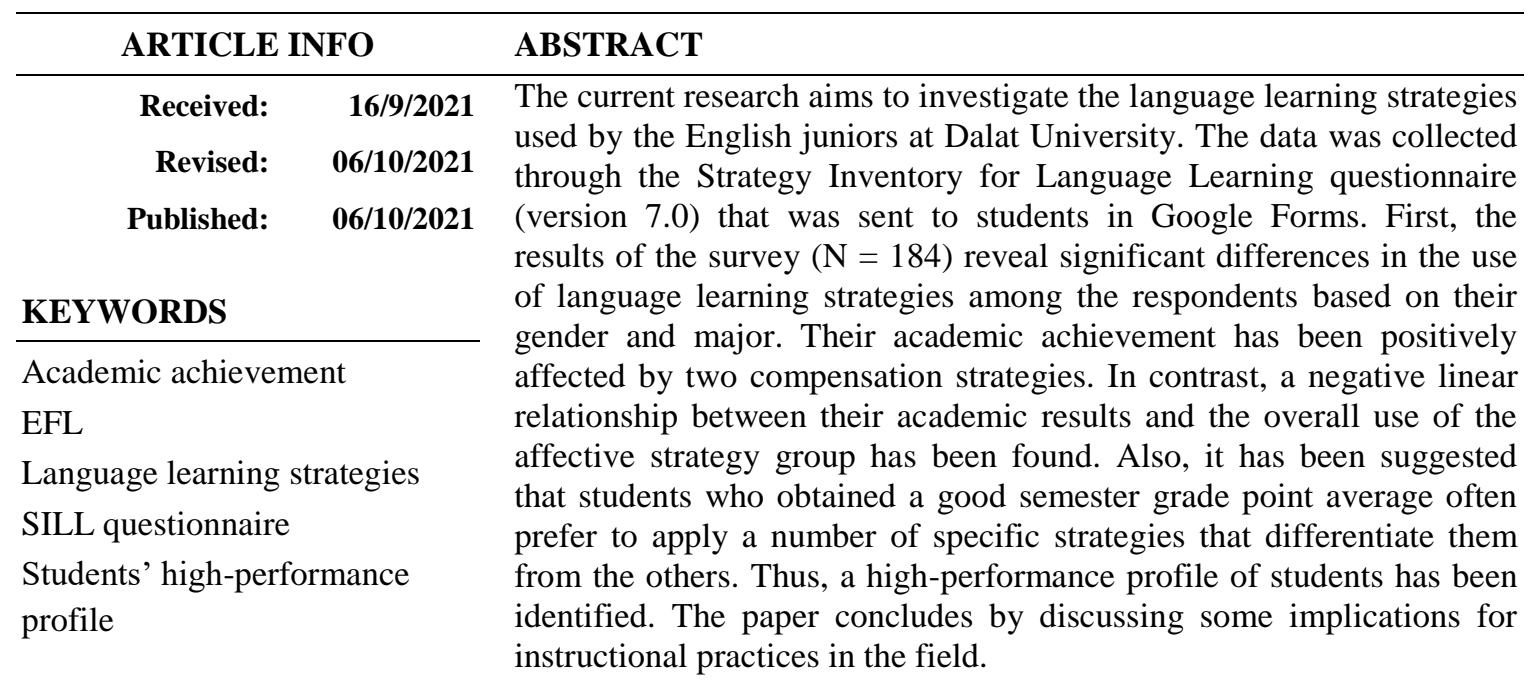

\section{CHIẾN LƯợC HỌC TẬP NGÔN NGŨ̉: NGHIÊN CÚU TRƯỜNG HỢP CỦA SINH VIÊN ANH VĂN NĂM THỨ BA TẠI TRƯỜNG ĐẠI HỌC ĐÀ LẠT}

\author{
Nguyễn Đỗ Thiên Vũ , Lê Văn Tuấn Khoa, Lê Thị Phương Hòa
}

Truờng Đại học Đà Lạt

\begin{tabular}{|c|c|}
\hline THÔN & \\
\hline Ngày nhận bài: & \multirow{10}{*}{ 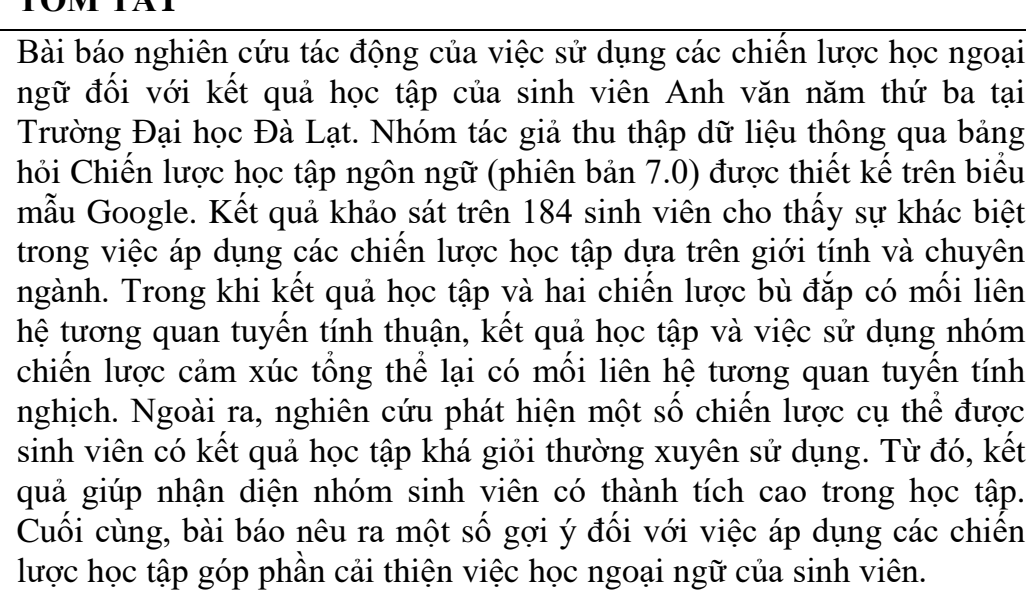 } \\
\hline Ngày hoàn thiện: $06 / 10 / 2$ & \\
\hline ing: $06 / 1$ & \\
\hline & \\
\hline TÙ & \\
\hline Kết & \\
\hline Tiếng Anh & \\
\hline c tập ngôn & \\
\hline $\operatorname{lng~h}$ & \\
\hline hh viên có thà & \\
\hline
\end{tabular}

DOI: $\underline{\text { https://doi.org/10.34238/tnu-jst.5055 }}$

\footnotetext{
*Corresponding author. Email: vundt@dlu.edu.vn
} 


\section{Introduction}

It is really important to apply appropriate learning strategies for a better outcome. Oxford developed a system of language learning strategies (LLSs) in the form of a questionnaire entitled The Strategy Inventory for Language Learning (SILL) [1]. The author contended that language learners could study effectively if they know how to use the strategies, particularly in learning English. In other words, the language skills can be acquired through a selection of adequate learning strategies that should be appropriate for the learners as well as suitable for their learning environment. Translated into different languages, the SILL questionnaire has been regarded as an important tool for evaluating one's own learning [2]. Moreover, some researchers considered Oxford's SILL questionnaire a reliable system of exhaustive LLSs that are more intelligible than that of other authors [3].

Thus far, many studies have revealed the important role of LLSs for learners who want to be successful in learning. The interest in learning strategies focusing on student-centered approach commenced in the 1970s and 1980s [4] - [6]. These strategies can be interpreted as "specific actions, behaviors, steps, or techniques that students (often intentionally) use to improve their progress in developing second language (L2) skills" [7]. Oxford studied the classification of LLSs by dividing them into two major groups called direct strategies and indirect strategies. The first group was then subdivided into three main categories encompassing 1) memory strategies; 2) cognitive strategies and 3) compensation strategies. The second group is also constituted of three subcategories including 1) metacognitive strategies; 2) affective strategies and 3) social strategies [1]. The author added that the last three indirect strategies mentioned above constitute an essential counterpart to the first three direct strategies. To put it another way, indirect strategies are used to consolidate the direct ones and facilitate the learning process [2], [3], [5]. In sum, LLSs are steps taken by students to enhance their own learning. They are regarded as important tools for their active and self-directed involvement that helps to develop language proficiency and gain more self-confidence. An effective use of LLSs can help language learners to improve both their high-performance profile and their self-efficacy profile [8], [9].

In recent years, the work on language learning strategies has significantly increased, especially on both English as a second language (ESL) and English as a foreign language (EFL). In line with a research in 1989 [10], many authors studied the relationship between learning strategies and academic performance of English learners. The results revealed that the more English learners use strategies, the better their language proficiency will be. It also suggested that female students tend to apply strategies in learning the language more frequently than male counterparts do. However, some results showed the opposite or no difference of the use of strategies in terms of gender. Particularly in Vietnam, there has been a limited number of studies on LLSs in teaching and learning English as a foreign language (EFL) [2], [7]. Only a few researches on LLSs in teaching and learning other languages such as French [11] or Chinese [12] have been recorded.

Over the last decade, the Ministry of Education and Training of Vietnam (MOET) implemented the project entitled "Teaching and Learning Foreign Languages in the National Education System, Period 2008 to 2020" to boost the quality of English language learning and teaching across all levels in the country. Thereby, teachers have tried their best to renew both teaching methods and curricula. They have also adhered to student-centered and interactive approaches. To meet the language proficiency requirements, teachers and learners have to concentrate on LLSs. The essential role of those strategies is emphasized in language teaching and learning, but there has been little research in this field [2], [7]. In consequence, some Vietnamese authors have reported that our students majoring in foreign languages do not know how to apply LLSs in an effective way in order to improve their learning and to achieve better results. It is the same with English majored students in Saudi Arabia who often have a poor proficiency and whose outcomes are unsatisfactory [13]. For 
instance, the social strategies that help to improve communication skills are most often ignored. They continue to study a living language in the same way as others did in the past: without a great deal of interaction with one another.

Despite the efforts of the MOET, English learners have not paid particular attention to social strategies since they do not have the habit of using a foreign language to communicate in Vietnamese settings. In the actual context, learners do not have frequent opportunities to practice speaking or to communicate with English speakers of native ones whereas Oxford considered communicative competence as the main goal [1]. To be more precise, English learners enhance language proficiency and build self-confidence in communication [7]. Indeed, the social constructivism and the conception of the zone of proximal development of Vygotsky emphasized the social interaction in the development of cognition and the co-construction of knowledge [14].

For all these above reasons, it is an opportune time to investigate, on the one hand, the frequency of the LLSs applied by English juniors at Dalat University (DLU) as well as the differences of the use of LLSs among them. On the other hand, the present research attempts to clarify the possible relationship between their use of learning strategies and their academic achievement. Additionally, it would be necessary to identify the students' high-performance profile that could be served as a reference for teaching and learning improvement. This paper also intends to put forward some recommendations for instructional practices.

\section{Methodology}

\subsection{Design of the research}

The current research was conducted using a quantitative approach. The online questionnaire was employed to investigate the LLSs used by the English juniors of DLU and explore, from statistics calculation, the possible relationship between their learning strategies and their semester grade point average (GPA). To its end, the present study needs to answer the following questions: 1) To what extent have English juniors of DLU applied LLSs in their learning? 2) What possible impacts might the use of LLSs have on students' academic achievement? 3) What could be the profile of good students based on their LLSs and GPA?

\subsection{Research population and instruments}

The research was conducted amongst DLU juniors majoring either in English for Business and Tourism (EBT), English for Translation and Interpretation (ETI), or EFL Teaching (ELT). In this paper, the English juniors refer to all third-year students majoring in each of the three majors offered by DLU. Also, the term of "high-performance profile" or "good students" exclusively means those who obtain a semester GPA ranging from 2.50 to 3.59 (classified as "good" according to the four-point scale). The SILL questionnaire, version 7.0 for EFL students [1], was utilized since it is considered the most effective tool and widely used including Asian countries (Quinquang, 2008, as cited in [2]), and the comprehensive and detailed taxonomy [15]. The questionnaire's author described three main profiles based on the overall average that indicates the frequency of the LLSs used by each learner: i) the low average subdivided into two levels: 1.0 - 1.4 labeled "Never or almost never used", and $1.5-2.4$ as "Generally not used"; ii) the medium average refering to $2.5-3.4$, labeled "Sometimes used"; iii) the high average subdivided into two levels: $3.5-4.4$, labeled "Usually used", and $4.5-5.0$ as "Always or almost always used". The questionnaire was put online in Google Forms and then sent to all English juniors. The data was analyzed using the SPSS software, version 20.

\section{Findings and discussion}

The online questionnaire was sent to 213 English juniors who were invited to give their answer from March 01, 2021 to April 30, 2021. There were 184 respondents (86.4\%), of which 
144 are female students $(78.3 \%)$ and 40 male counterparts $(21.7 \%)$. The prevailing number of females has also been documented in other research [3], [8] - [10], [12]. The EBT major has the biggest number of respondents, 94 students $(51.1 \%)$; 60 respondents $(32.6 \%)$ majoring in ETI; only 30 respondents (16.3\%) belonging to ELT. Out of 184 respondents, only $45(24.5 \%)$ managed to obtain a GPA ranging from 2.50 to 3.59 during the first semester of 2020-2021. The academic results have also been reported to be poor in another research in Vietnam [3]. The fact that these two GPA ranks are combined is because only three students got 3.20-3.59. Additionally, female students use strategies more frequently than their male peers $(\mathrm{M}=3.44$ and $\mathrm{M}=3.29$ respectively). This result is the same as some previous findings [3], [10]. However, Vietnamese students of Chinese language have a high frequent use of LLSs [12]. The large proportion of females also reveal that they often choose to study in the social sciences and humanities and that they select their major based on the labor market needs. In Vietnam, there are fewer job opportunities for pedagogy or translation/interpretation graduates than business/tourism graduates. Such a large majority of females and their frequent use of LLSs corresponds to some other studies of Vietnamese researchers such as [2], [3].

\subsection{The overall use of LLSs}

Table 1. The frequency of LLSs reported by English juniors of DLU

\begin{tabular}{llccc}
\hline \multicolumn{1}{c}{ Strategy group } & Mean & $\begin{array}{c}\text { Std. } \\
\text { Deviation }\end{array}$ & Rank \\
\hline A. Memory strategies & (9 items: A1-A9) & 3.2917 & 0.55956 & 5 \\
B. Cognitive strategies & (14 items: B10-B23) & 3.4418 & 0.53399 & 3 \\
C. Compensation strategies & (6 items: C24-C29) & 3.3913 & 0.58800 & 4 \\
D. Metacognitive strategies & (9 items: D30-D38) & 3.5676 & 0.59761 & 1 \\
E. Affective strategies & $(6$ items: E39-E44) & 3.2862 & 0.67067 & 6 \\
F. Social strategies & (6 items: F45-F50) & 3.4991 & 0.68829 & 2 \\
Overall & & 3.4130 & 0.47704 & \\
\hline
\end{tabular}

Table 1 shows that on the whole, the English juniors of DLU use six learning strategies with medium frequency $(\mathrm{M}=3.41 ; \mathrm{SD}=0.47)$. These results are similar to those obtained in the previous study of Nguyen, et al. [2], but Luu [12] revealed that Chinese-Vietnamese students had an overall use of strategies in learning Chinese with high frequency $(\mathrm{M}=3.66)$. As it is noticed, the LLSs used as follows: metacognitive strategy group $(M=3.56)$, social strategies $(M=3.49)$, cognitive strategies $(M=3.44)$, compensation strategies $(M=3.39)$, memory strategies $(M=$ 3.29), affective strategies $(M=3.28)$. Apparently, the students focus primarily on organizing and evaluating their learning to study English more effectively, by contrast they might not know how to manage their emotions to improve their learning. Besides, the social strategies have been considered the second important strategy group that enables them to practice English everywhere and anytime. These three strategy groups with high average are also similar to other findings [12, 13]. The fact that least frequent refers to the affective strategies corresponds to another study [15]; however, it is not the case that Asian students often prefer the memory strategies, as reported by these authors. The low average of other LLSs such as cognitive strategies, compensation strategies, and memory strategies might be interpreted as their lack of awareness of the importance of using all strategies in developing their English competency [13]. For instance, the Vietnamese respondents do not frequently use mnemonics to learn the language, possibly because they are not familiar with these kinds of techniques or maybe they have not been taught how to use them. 


\subsection{The difference in the use of LLSs amongst male and female students}

The independent-samples $t$-tests as partially presented in Table 2 show that there are statistically significant differences (with $p$-value less than 0.05 ) in only seven strategies, which have been employed more frequently by female respondents than their male counterparts. The social strategies include three items, F45: $\mathrm{t}(182)=-3.32, \mathrm{p}=0.00 ; \mathrm{F} 47: \mathrm{t}(182)=-1.98, \mathrm{p}=0.04$; and F48: $\mathrm{t}(182)=-2.19, \mathrm{p}=0.02$. The affective strategies consist of two items, $\mathrm{E} 41: \mathrm{t}(182)=-$ $2.89, \mathrm{p}=0.00$ and $\mathrm{E} 44: \mathrm{t}(182)=-2.30, \mathrm{p}=0.02$. Only memory strategies and cognitive strategies preferred by female respondents contain one item each, A7: $\mathrm{t}(182)=-2.30, \mathrm{p}=0.02$ and item B11: $t(182)=-2.46, p=0.01$ respectively. Firstly, female students often prefer to learn with their peers and practice with English speakers. They do not feel shy asking for help and they have proven to be more sociable than their male fellows. Next, females naturally tend to be more emotionally expressive than males. Consequently, they often manage to know how to encourage themselves in learning and talk about how they feel about their learning. Then, physically acting out helps them to memorize new vocabulary in English. It is also believed that acting out reduces stress. Hence, this is a good way to learn a language. Finally, by nature female students are usually fond of acting and imitating native speakers since they might feel more charming.

Table 2. Independent-Samples t-Tests for LLSs used by English juniors based on gender

\begin{tabular}{|c|c|c|c|c|c|c|}
\hline & Gender & $\mathbf{N}$ & $\mathbf{M}$ & SD & $\mathbf{T}$ & $\begin{array}{l}\text { Sig }(2- \\
\text { tailed })\end{array}$ \\
\hline \multirow{2}{*}{$\begin{array}{l}\text { A7. I physically act out new English } \\
\text { words. (Memory strategies) }\end{array}$} & Male & 40 & 2.9 & 1.033 & \multirow{2}{*}{-2.30} & \multirow{2}{*}{0.023} \\
\hline & Female & 144 & 3.26 & 0.817 & & \\
\hline \multirow{2}{*}{$\begin{array}{l}\text { B11. I try to talk like native English } \\
\text { speakers. (Cognitive strategies) }\end{array}$} & Male & 40 & 3.33 & 0.997 & \multirow{2}{*}{-2.46} & \multirow{2}{*}{0.015} \\
\hline & Female & 144 & 3.74 & 0.916 & & \\
\hline \multirow{2}{*}{$\begin{array}{l}\text { E41. I give myself a reward or treat when I } \\
\text { do well in English. (Affective strategies) }\end{array}$} & Male & 40 & 2.68 & 1.095 & \multirow{2}{*}{-2.89} & \multirow{2}{*}{0.004} \\
\hline & Female & 144 & 3.24 & 1.084 & & \\
\hline \multirow{2}{*}{$\begin{array}{l}\text { E44. I talk to someone else about how I } \\
\text { feel when I am learning English. } \\
\text { (Affective strategies) }\end{array}$} & Male & 40 & 2.9 & 1.15 & \multirow[b]{2}{*}{-2.30} & \multirow[b]{2}{*}{0.022} \\
\hline & Female & 144 & 3.35 & 1.066 & & \\
\hline \multirow{2}{*}{$\begin{array}{l}\text { F45. If I do not understand something in } \\
\text { English, I ask the other person to slow } \\
\text { down or say it again. (Social strategies) }\end{array}$} & Male & 40 & 3.43 & 0.781 & \multirow[b]{2}{*}{-3.32} & \multirow[b]{2}{*}{0.001} \\
\hline & Female & 144 & 3.92 & 0.853 & & \\
\hline \multirow{2}{*}{$\begin{array}{l}\text { F47. I practice English with other students. } \\
\text { (Social strategies) }\end{array}$} & Male & 40 & 3.3 & 1.018 & \multirow{2}{*}{-1.98} & \multirow{2}{*}{0.049} \\
\hline & Female & 144 & 3.63 & 0.914 & & \\
\hline \multirow{2}{*}{$\begin{array}{l}\text { F48. I ask for help from English speakers. } \\
\text { (Social strategies) }\end{array}$} & Male & 40 & 3.08 & 1.118 & \multirow{2}{*}{-2.19} & \multirow{2}{*}{0.029} \\
\hline & Female & 144 & 3.49 & 1.051 & & \\
\hline
\end{tabular}

\subsection{The difference in the use of LLSs amongst three majors}

The one-way Anova test as shown in Table 3 reveals that significant differences (with $p$-value less than 0.05) exist in five strategies applied by respondents majoring either in EBT, ETI, or ELT. These significant differences are all sorted in descending order. The analysis of the data using post hoc tests indicates that two items B20 and B21 belonging to cognitive strategies: 1) ETI, 2) EBT and 3) ELT, with $p=0.01$ and $p=0.00$ respectively. The item C26 referring to compensation strategies is in reverse order in two first majors: 1) EBT, 2) ETI and 3) ELT, with $p=0.02$. The next item D37 is listed: 1) EBT, 2) ELT and 3) ETI, with $p=0.02$. And the last item E41 is in the same order as item C26: 1) EBT, 2) ETI and 3) ELT, with $p=0.01$. It has been suggested in this finding that participants majoring either in ETI or EBT use the five strategies above more frequently than those majoring in ELT do. This may be interpreted in such a way that the major allows students to be more flexible in terms of use of learning strategies, for instance, students majoring in ELT are often perceived as less dynamic than those majoring in other fields of study since they would only work with their students and collaborate with their peers. In addition to this, 
there is a significant difference in using strategy groups between the three majors. The affective strategies are the least used group by ELT students for they might think that teachers need to have the ability to control their emotions in teaching environment. In this regard, the teaching profession in Vietnam often requires honesty, equity, and integrity rather than pure emotions.

Table 3. One-way ANOVA test for LLSs used by English juniors based on major

\begin{tabular}{|c|c|c|c|c|c|c|}
\hline & & $\begin{array}{c}\text { Sum of } \\
\text { Squares }\end{array}$ & df & $\begin{array}{c}\text { Mean } \\
\text { Square }\end{array}$ & $\mathbf{F}$ & Sig. \\
\hline \multirow{3}{*}{$\begin{array}{l}\text { B20. I try to find patterns in } \\
\text { English. } \\
\text { (Cognitive strategies) }\end{array}$} & Between Groups & 5.440 & 2 & 2.720 & \multirow[t]{3}{*}{4.067} & \multirow[t]{3}{*}{0.019} \\
\hline & Within Groups & 121.060 & 181 & 0.669 & & \\
\hline & Total & 126.500 & 183 & & & \\
\hline \multirow{3}{*}{$\begin{array}{l}\text { B21. I find the meaning of an } \\
\text { English word by dividing it into } \\
\text { parts that I understand. } \\
\text { (Cognitive strategies) }\end{array}$} & Between Groups & 13.015 & 2 & 6.507 & \multirow[t]{3}{*}{7.184} & \multirow[t]{3}{*}{0.001} \\
\hline & Within Groups & 163.942 & 181 & 0.906 & & \\
\hline & Total & 176.957 & 183 & & & \\
\hline \multirow{3}{*}{$\begin{array}{l}\text { C26. I make up new words if I } \\
\text { do not know the right ones in } \\
\text { English. } \\
\text { (Compensation strategies) }\end{array}$} & Between Groups & 6.448 & 2 & 3.224 & \multirow[t]{3}{*}{3.646} & \multirow[t]{3}{*}{0.028} \\
\hline & Within Groups & 160.052 & 181 & 0.884 & & \\
\hline & Total & 166.500 & 183 & & & \\
\hline \multirow{3}{*}{$\begin{array}{l}\text { D37. I have clear goals for } \\
\text { improving my English skills. } \\
\text { (Metacognitive strategies) }\end{array}$} & Between Groups & 6.416 & 2 & 3.208 & \multirow[t]{3}{*}{3.617} & \multirow[t]{3}{*}{0.029} \\
\hline & Within Groups & 160.519 & 181 & 0.887 & & \\
\hline & Total & 166.935 & 183 & & & \\
\hline \multirow{3}{*}{$\begin{array}{l}\text { E41. I give myself a reward or } \\
\text { treat when I do well in English. } \\
\text { (Affective strategies) }\end{array}$} & Between Groups & 10.114 & 2 & 5.057 & \multirow[t]{3}{*}{4.267} & \multirow[t]{3}{*}{0.015} \\
\hline & Within Groups & 214.490 & 181 & 1.185 & & \\
\hline & Total & 224.603 & 183 & & & \\
\hline
\end{tabular}

\subsection{The relationship between use of LLSs and semester GPA}

Table 4. Pearson correlations between LLSs and semester GPA

\begin{tabular}{llccccccc}
\hline & & GPA & C24 & C25 & C26 & C27 & C28 & C29 \\
\hline \multirow{6}{*}{ GPA } & Pearson & 1 & 0.056 & $0.157^{*}$ & -0.070 & 0.025 & -0.104 & $0.178^{*}$ \\
& Correlation & & & & & & & \\
& Sig. (2-tailed) & & 0.448 & 0.033 & 0.347 & 0.735 & 0.160 & 0.015 \\
& N & 184 & 184 & 184 & 184 & 184 & 184 & 184 \\
\hline \multirow{2}{*}{ GPA } & Pearson & 1 & -0.141 & -0.109 & 0.059 & -0.028 & $-0.237^{* *}$ & -0.021 \\
& Correlation & & & & & & & \\
& Sig. (2-tailed) & & 0.056 & 0.141 & 0.428 & 0.706 & 0.001 & 0.780 \\
& N & 184 & 184 & 184 & 184 & 184 & 184 & 184 \\
\hline
\end{tabular}

*. Correlation is significant at the 0.05 level (2-tailed).

**. Correlation is significant at the 0.01 level (2-tailed).

As represented in table 4, the Pearson's $r$ statistic reveals certain positive correlations between two items C25 "When I can't think of a word during a conversation in English, I use gestures." $(\mathrm{r}=0.15 ; \mathrm{p}=0.03)$ and C29 "If I can't think of an English word, I use a word or phrase that means the same thing." $(\mathrm{r}=0.17 ; \mathrm{p}=0.01)$ pertaining to compensation strategies applied by respondents and their semester GPA. This finding has suggested that the more they apply these two strategies in their learning, the better their score will get. Thus, students have become more confident, natural and more "Western-like" to some extent when speaking English because gestures are often not really appreciated in Asian settings, particularly in Vietnam. In contrast, the affective strategy group is negatively correlated with the respondents' semester GPA $(\mathrm{r}=-0.23 ; \mathrm{p}=0.00)$. This implies in this case a paradox following which good management of their own emotions in learning English does not help with their academic achievement. In other words, the more they apply the affective strategy group, the less effective their performance will 
be. At all events, this should be considered a peculiar finding within this research. Such a finding is different from the work of [3] that showed no correlations between the use of LLSs and academic results.

\subsection{Students' high-performance profile based on their most preferable LLSs}

Table 5. The high-average LLSs applied by respondents having obtained a good semester GPA

\begin{tabular}{lrr}
\hline \multicolumn{1}{c}{ Strategies } & Mean & $\begin{array}{c}\text { Std. } \\
\text { Deviation }\end{array}$ \\
\hline A2. I use new English words in a sentence so I can remember them. & 3.67 & 0.879 \\
\hline $\begin{array}{l}\text { B15. I watch English language TV shows spoken in English or go to movies } \\
\text { spoken in English. }\end{array}$ & 4.02 & 0.965 \\
B12. I practice the sounds of English. & 3.82 & 0.886 \\
B11. I try to talk like native English speakers. & 3.60 & 1.136 \\
\hline C29. If I can't think of an English word, I use a word or phrase that means the & 4.07 & 0.751 \\
same thing. & 3.78 & 0.927 \\
C25. When I can't think of a word during a conversation in English, I use gestures. & 3.73 & 0.751 \\
C24. To understand unfamiliar English words, I make guesses. & 3.89 & 0.910 \\
\hline D33. I try to find out how to be a better learner of English. & 3.89 & 0.682 \\
D32. I pay attention when someone is speaking English. & 3.76 & 0.712 \\
D31. I notice my English mistakes and use that information to help me do better. & 3.62 & 0.834 \\
D30. I try to find as many ways as I can to use my English. & 3.51 & 0.968 \\
D37. I have clear goals for improving my English skills. & 3.71 & 0.944 \\
\hline E40. I encourage myself to speak English even when I am afraid of making a & & \\
mistake. & 3.51 & 1.079 \\
E39. I try to relax whenever I feel afraid of using English. & 3.76 & 0.857 \\
\hline F45. If I do not understand something in English, I ask the other person to slow & & \\
down or say it again. & 3.53 & 0.991 \\
F47. I practice English with other students. & 3.53 & 0.894 \\
\hline F46. I ask English speakers to correct me when I talk. & & \\
\hline Valid N (listwise) 45 & &
\end{tabular}

Table 5 clearly reveals the 17 most frequently used strategies by 45 juniors (seven males and 38 females) who achieved, in the $1^{\text {st }}$ semester of 2020-2021, a good semester GPA ranging from 2.50-3.59. These strategies are sorted in descending order based on average within their group. Firstly, there is only one item A2 belonging to memory strategies $(\mathrm{M}=3.67$; $\mathrm{SD}=0.87)$. Then, the cognitive strategies contribute three items, namely B15 $(\mathrm{M}=4.02 ; \mathrm{SD}=0.96), \mathrm{B} 12(\mathrm{M}=$ 3.82, $\mathrm{SD}=0.88)$ and $\mathrm{B} 11(\mathrm{M}=3.60 ; \mathrm{SD}=1.136)$. Next, three items referring to compensation strategies are $\mathrm{C} 29(\mathrm{M}=4.07 ; \mathrm{SD}=0.75), \mathrm{C} 25(\mathrm{M}=3.78 ; \mathrm{SD}=0.92)$ and $\mathrm{C} 24(\mathrm{M}=3.73 ; \mathrm{SD}=$ 0.75). The metacognitive strategies provide with five items, especially D33 and D32 with highest average $(\mathrm{M}=3.89 ; \mathrm{SD}=0.91, \mathrm{SD}=0.68$ respectively $)$, and $\mathrm{D} 37$ with lowest average in this group $(\mathrm{M}=3.51 ; \mathrm{SD}=0.96)$. After that, two items $\mathrm{E} 40(\mathrm{M}=3.71 ; \mathrm{SD}=0.94)$ and $\mathrm{E} 39(\mathrm{M}=$ $3.51 ; \mathrm{SD}=1.07)$ the affective strategies. Finally, three items relating to social strategies have been recorded as F45 $(\mathrm{M}=3.76 ; \mathrm{SD}=0.85), \mathrm{F} 47(\mathrm{M}=3.53 ; \mathrm{SD}=0.99)$ and $\mathrm{F} 46(\mathrm{M}=3.53$; SD $=0.89$ ). This finding shows a fairly equal proportion of items pertaining to six strategy groups, except memory strategies. Perhaps remembering what one learns is simply a requirement inherent in learning or maybe this type of strategy is becoming inadequate in an era of information explosion. It is actually impossible to memorize a literally massive and rapid flow of information every day. In contrast, it is important to notice from these results that one can learn a language much more effectively by using all mental processes, and organizing and evaluating his or her learning. Hence, without metacognitive strategies, students possibly lack "directions and opportunities to monitor their progress, and plan their learning or review their accomplishments" 
[13, p. 68]. In general, Vietnamese learners are not really good at learning foreign languages, especially English. It cannot be denied that there are significant gaps in language that oblige learners to know how to compensate for missing knowledge. It is important to notice that these 45 respondents with good semester GPA also use two affective strategies to help them learn English more effectively. This implies that good students would surely know how to manage their emotions in order to better perform in their learning. Nevertheless, this detail is in contradiction with the confirmation that there has been a negative correlation between the use of affective strategies and the score of all 184 respondents (see 3.4 above). As a final point, language competency is usually and clearly reflected in the ability to communicate orally and in writing with other people. As a result, effective language learning means learning with others and needs interaction with each other.

\section{Conclusion}

The findings reveal that the English juniors of DLU have used LLSs with a medium overall average. Females tend to apply language learning strategies more frequently than males, specifically in seven strategies covering four strategy groups. However, teachers should raise students' awareness of the importance of all LLSs and create more opportunities for them to use all these strategies. Significant differences between five strategies and the respondents' major have been documented. Consequently, teachers should invite ELT students to apply metacognitive strategies more often to help them to plan their future teaching and monitor their future students' progress. EBT students and ETI students should engage in strategies that will help them to be more dynamic, flexible and productive by focusing more often on cognitive strategies and compensation strategies. Besides, although two strategies pertaining to the compensation strategy group and the respondents' semester GPA are positively correlated, there has been a negative linear relationship between the overall use of the affective strategy group and their semester GPA. Such a finding suggests that, on the one hand, compensation strategies should be thoroughly explored to assist students in overcoming limitations of their knowledge in the target language. On the other hand, further research on the impact of affective strategies on students' performance should be implemented to clarify this finding. In fact, the more students manage their emotions well, the more confident they will be. The control of feeling will definitely involve the whole learning process.

In addition to this, the profile of a good student exclusively based on his or her GPA provides a general picture of effective strategies that should be used to improve one's academic achievement. As educators, teachers should concentrate on these 17 specific strategies to help other students with poor performance. It is obvious that cognitive and metacognitive strategies are essential for effective learning, whereas social strategies help to improve communication skills. Apparently, English learners should know how to compensate for missing knowledge in case their linguistic proficiency is still low. Moreover, English teachers ought to introduce additional mnemonics to students to help them memorize the learning content and techniques used to manage emotions. In fact, a frequent use of all LLSs in learning EFL is strongly recommended for language learners who want to study the language more effectively and improve English proficiency [1]. Hence, in the teaching and learning process teachers should focus more on all strategies to help students to improve their academic performance. It cannot be denied that cooperative learning definitely helps attain greater and more rapid achievement. English teachers should create more social interaction opportunities for students as well as encourage them to cooperate with one another. Finally, further research should be conducted to gain deeper insights into the use of LLSs by non-English majored students within Vietnam. 


\section{REFERENCES}

[1] R. L. Oxford, Language learning strategies-What every teacher should know. Heinle \& Heinle, 1990.

[2] T. D. Nguyen, H. T. Trinh, and M. T. Huynh, "Language learning strategies used by non-English major freshman at Can Tho University," Can Tho University Journal of Science, no. 23b, pp. 42-49, 2012.

[3] T. D. Nguyen, H. T. Trinh, and M. T. Huynh, "The correlation between language learning strategy use of English non-major freshman and their achievements in the course General English 1, at Can Tho University," Can Tho University Journal of Science, no. 24b, pp. 100-107, 2012.

[4] J. Atlan, "Language learning strategies: definitions, typologies, research methodologies," Cahiers de l'APLIUT, vol. 16, no. 3, pp. 9-17, 1997.

[5] K. Szymankiewicz, "The complexity of factors influencing the ineffective use of language learning strategies - A case study," Synergies Pologne, no. 9, pp. 49-62, 2012.

[6] R. Tokiwa, R. Mogi, M. Himeta, S. Tanaka, S. Harada, and K. Muroi, "Qualitative analysis of learning strategies in a language training course," Japanese journal of French teaching, vol. 32, pp. 67-85, 2004.

[7] B. T. K. Giang and V. V. Tuan, "Language Learning Strategies of Vietnamese EFL Freshmen," Arab World English Journal, vol. 9, no. 3, pp. 61-83, 2018, doi: 10.24093/awej/vo19no3.5.

[8] D.-H. Kim, C. Wang, H. S. Ahn, and M. Bong, "English language learners' self-efficacy profiles and relationship with self-regulated learning strategies," Learning and Individual Differences, vol. 38, pp. 136-142, 2015, doi: 10.1016/j.lindif.2015.01.016.

[9] Y. Wang, B. Shen, and X. Yu, "A latent profile analysis of EFL learners' self-efficacy: Associations with academic emotions and language proficiency," System, vol. 103, 2021, art. no. 102633, doi: 10.1016/j.system.2021.102633.

[10]R. Oxford and M. Nyikos, "Variables affecting choice of language learning strategies by university students," The modern language journal, vol. 73, no. 3, pp. 291-300, 1989.

[11]H. B. Nguyen, "Reliability assessement of Vietnamese version of Oxford's Strategy Inventory For Language Learning on Vietnamese learners of French," Journal of Science and Technology - The University of Danang, vol. 5, no. 40, pp. 21-27, 2010.

[12]H. V. Luu, "Learning strategies by Vietnamese Chinese students in Ho Chi Minh City," Ho Chi Minh City University of Education Journal of Science, vol. 16, no. 11, pp. 799-808, 2019.

[13]B. A. Al-Khaza'le, "Exploring language learning strategies of Saudi EFL learners at Shaqra University, Saudi Arabia," Advances in Language and Literary Studies, vol. 10, no. 4, pp. 63-71, 2019.

[14]L. S. Vygotsky, Thought and language, A. Kozulin and Trans. A. Kozulin Ed. Cambridge, MA \& London, UK: The MIT Press, 1986.

[15]M. Nemati, M. A. S. Nodoushan, and A. Ashrafzadeh, "Learning Strategies in Proficient and Less Proficient Readers in Medicine," Journal on Educational Psychology, vol. 4, no. 2, pp. 19-32, 2010. 